\title{
Estimation of physiological parameters on high density plantations and population arrangements of Musa AAA Simmonds
}

\section{Estimación de parámetros fisiológicos en altas densidades de plantación y arreglo poblacional de Musa AAA Simmonds}
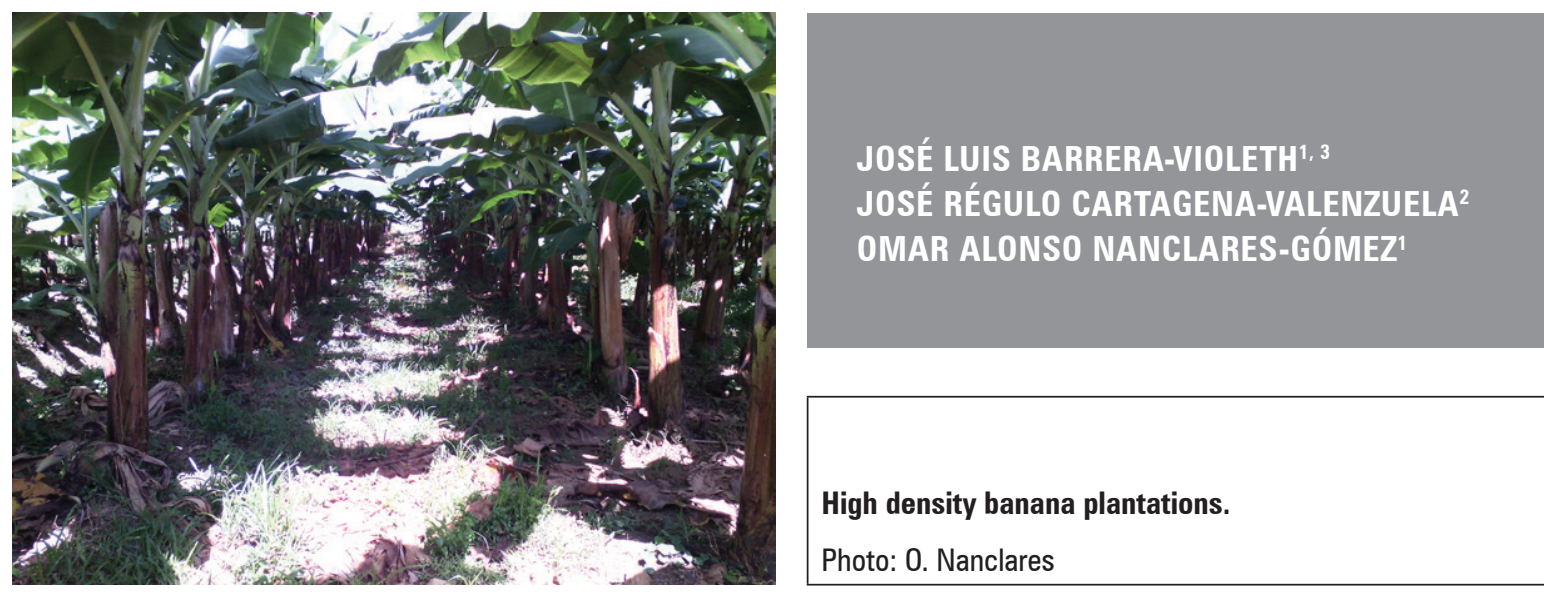

\section{ABSTRACT}

In Uraba, Antioquia (Colombia), there is a shortage of first-semester fruits and a surplus of second-semester fruits as a result of low or high precipitation, respectively, affecting the value of production. An experiment was established during 2015-2016 in an area representative of the region in order to determine the field distribution and plantation density that maximize the agronomic potential of Musa AAA Simmonds cv. Williams. The population arrangement treatments (rectangle, triangle and double row), planting densities $(2,000 ; 2,500 ; 3,000$ and 3,500 plants/ha) and one control (1,700 plants/ha in a triangle) were evaluated in a complete, random block design with three repetitions. In the phenological phases of floral differentiation, flowering and harvest, the gas exchange was quantified with measurements of the photosynthesis rate, internal $\mathrm{CO}_{2}$ concentration, stomatal conductance, transpiration, vapor pressure deficit, and water use efficiency. The leaf temperature, quantum photosynthesis efficiency and efficient use of radiation were also considered. The yield components and fruit quality were estimated with fruit mass, number of hands, number of fruits, length of the last hand and degree of the second and last hand. The results showed that the density 2,500 plants/ha, distributed in a triangle or double row, promoted the best use of the climate elements associated with photosynthetic activity under the environmental conditions of Uraba, Antioquia.

Additional key words: gas exchange; tropical fruits; water relations; agronomic management; fruit quality.

Universidad de Córdoba, Facultad de Ciencias Agrícolas, Monteria (Colombia). ORCID Barrera-Violeth, J.L.: 0000-0001-9104-0099

2 Universidad Nacional de Colombia, Sede Medellín, Facultad de Ciencias Agrarias, Medellin (Colombia). ORCID Cartagena-Valenzuela, J.R.: 0000-0001-6196-2439; ORCID Nanclares-Gómez, O.A.: 0000-0002-9843-934X

Corresponding author: jlbarrera@correo.unicordoba.edu.co 


\section{RESUMEN}

En el Urabá antioqueño (Colombia) se presenta una escasez de fruto en el primer semestre y una sobreoferta en el segundo semestre, motivada por la baja o alta precipitación respectivamente, situación que afecta el valor de la producción. Se estableció durante los años 2015-2016 en un lugar representativo de la región, un experimento con el objetivo de determinar la distribución en campo y la densidad de plantación que contribuyan a maximizar el potencial agronómico de Musa AAA Simmonds cv. Williams. Los tratamientos arreglo poblacional (rectángulo, triángulo y doble surco) y las densidades de plantación (2.000, 2.500, 3.000 y 3.500 plantas/ha; y un testigo (1.700 plantas/ha en triángulo), se evaluaron en un diseño de bloques completos al azar con tres repeticiones. En las fases fenológicas de diferenciación floral, floración y cosecha, el intercambio de gases se cuantificó con mediciones de tasa de fotosíntesis, concentración interna de $\mathrm{CO}_{2}$ conductancia estomática, transpiración, déficit de presión de vapor y eficiencia en el uso del agua. También se tuvieron en cuenta la temperatura de la hoja, la eficiencia cuántica de fotosíntesis y el uso eficiente de la radiación. Los componentes de rendimiento y la calidad del fruto se estimaron con la masa del fruto, numero de manos, numero de dedos, longitud de la última mano y grado de la segunda y última mano. Los resultados demostraron que la densidad de 2.500 plantas/ha distribuidas en triángulo o doble surco, promovió el mejor uso de los elementos del clima asociados con la fijación de $\mathrm{CO}_{2}$ en las condiciones ambientales de Urabá, Antioquia.

Palabras clave adicionales: intercambio gaseoso; frutos tropicales; relaciones hídricas; manejo agronómico; calidad del fruto.

Received for publication: 17-06-2020 Accepted for publication: 23-11-2020

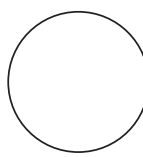

INTRODUCTION

India leads banana production with $18 \%$ of the global harvest, 139 million t year ${ }^{-1}$ Santosh et al., 2017). However, in terms of exporting countries, Ecuador ranks number one with $6,685,000 \mathrm{t}$, while Colombia occupies fourth place with 1,806,000 t, after the Philippines $(3,950,000 \mathrm{t})$, Guatemala $(2,494,000 \mathrm{t})$ and Costa Rica (2,200,000 t) (FAO, 2020). In Colombia, the average productivity in 2018 was 2,002 boxes/ha, equivalent to $36 \mathrm{t} \mathrm{ha}^{-1}$ and higher than that 2017 (AUGURA, 2018). The climatic behavior that characterizes the Uraba region, dry in the first half of the year and wet in the second half (Toro et al., 2016), directly affects production, generating shortage in the first half and surpluses in the second half, which directly affects international prices (AUGURA, 2017; 2018).

The photosynthetic process in plantains and bananas is controlled by internal factors, such as the genetic material, state of leaf development, integrity of the leaf blade, and by external factors, such as seasonality, daily climate, photosynthetically active radiation (PAR), shading and watering regime (Turner et al., 2009; Ramirez et al., 2011; Robinson and Galán, 2010). In Musaceae, external factors from the competition for sunlight within the plant community (Cayón et al., 2004) and for water severely affect production (Cayón, 2004; Santos et al., 2018). On the other hand, intrinsic factors, such as low tolerance to water stress, in banana cultivars with a dominance of acuminata genes (Ravi et al. 2013) and physiological factors, such as premature stomatal closure, significantly influence the efficiency of plants (Surendar, 2015). However, proper management of density and arrangement between plants can control or decrease these effects and increase yield per unit area as a result of the efficient use of sunlight and water during the early phases of crop growth.

Rodríguez et al. (2007) asserted that arrangements between plants facilitate better distribution in the field and a greater interception of solar radiation. In bananas, the double row arrangement increased the number of plants per hectare and production through an increase in the Leaf Area Index (LAI), which is a determining factor in PAR interception (Patil et al., 2018). Consequently, LAI plays an important role in the design of cultivation systems since, by varying the spacing between plants, the light interception, vigor of plants and yield are affected. Therefore, decreasing the distance between plants means LAI increases the efficiency for intercepting incident solar radiation but increases the light extinction coefficient ( $\mathrm{k}$ ) of the crop (Rodríguez et al., 2007; Turner et al., 2007). 
Thippesha et al. (2008) stated that, by reducing the distance between banana plants, the intensity of available light decreased for the middle and lower strata of the plants, along with the rate of photosynthesis, but did not influence the production of dry matter per plant or flowering time. However, the timing of the harvest and ripening of fruits are delayed as the plant density increases. According to Benson (2013), a planting density over 2,000 plants/ha alters the growth and development of plants because of the superposition of roots and overlapping of leaves, which generate excessive shade, causing a low bunch mass.

Vargas and Sandoval (2005) and Smith et al. (2010) suggested the need to validate the behavior of physiological variables in response to increases in plantation densities in banana crops. Because of the lack of information on the phenotypic plasticity of cv. Williams, which is the most cultivated plant under the agroecological conditions of Uraba, Antioquia, this study aimed to evaluate the effect of planting densities and arrangements between plants on the photosynthetic potential of the plant community and productivity under the climatic conditions of the region.

\section{MATERIALS AND METHODS}

This study was carried out during the second semester of 2015 and the first semester of 2016 on the La Venturosa farm of the Bananeras del Uraba Company in Turbo, Antioquia, located at $07^{\circ} 53^{\prime} \mathrm{N}$ and $76^{\circ} 41^{\prime} \mathrm{W}$ with the characteristics of a very humid tropical forest. The predominant bioclimatic parameters at the site during the study were a cumulative precipitation of 3,194 mm, higher in the second half of 2016 with $1,718 \mathrm{~mm}$, an average monthly maximum and minimum temperature of $32.1^{\circ} \mathrm{C}$ and $22.3^{\circ} \mathrm{C}$, respectively, a relative humidity of $87.01 \%$, and a monthly solar brightness of 112.36 light hours. The soil presented the geomorphological position of terraces, flat relief developed from alluviums of different granulometry, medium depth with moderate internal drainage, silty clay loam texture and medium fertility, which made it representative of the Inceptisol order (IGAC, 2007).

The physical and chemical characteristics of the soil were: clay loam texture, with a $\mathrm{pH}$ of 5.85 ; organic matter (OM) of $1.73 \%$; $\mathrm{Ca}$ and $\mathrm{Mg}$ of 10.3 and 3.11 $\mathrm{cmol}^{+} \mathrm{kg}^{-1}$, a slightly wide ratio (3.31) that could infer a $\mathrm{Mg}$ deficiency; $\mathrm{K}$ of $0.71 \mathrm{cmol}^{+} \mathrm{kg}^{-1}$; Effective Cation Exchange Capacity (ECEC) of $14.2 \mathrm{cmol}^{+} \mathrm{kg}^{-1}$;
$\mathrm{P}$ and $\mathrm{S}$ of 21.4 and $32.32 \mathrm{mg} \mathrm{kg}^{-1} ; \mathrm{Zn}$ and $\mathrm{Cu}$ of 2.4 and $3.1 \mathrm{mg} \mathrm{kg}^{-1}$; B of $0.54 \mathrm{mg} \mathrm{kg}^{-1}$; $\mathrm{Mn}$ of $0.54 \mathrm{mg} \mathrm{kg}^{-1}$ and $\mathrm{Fe}$ of $32.3 \mathrm{mg} \mathrm{kg}^{-1}$. Based on these results and the nutritional requirements indicated by Torres (2016), the corresponding amendments were applied.

The cv. Williams plantlets obtained by in vitro culture were established in $40 \times 40 \times 40 \mathrm{~cm}$ holes, based on the design of the treatments presented in table 1. The phytosanitary management of pests, diseases (not including black sigatoka (Mycosphaerella fijiensis Morelet), weeds and cultural tasks such as: thinning, stripping, and phytosanitary defoliation were carried out cyclically in accordance with the technical recommendations of the technical assistance unit of the Bananeras de Uraba group, made in response to the suggestions of the marketing company UNIBAN.

Table 1. Description of the treatments, based on the combination of four plantation densities and three population arrangements in the banana crop (cv. Williams Musa AAA Simmonds).

\begin{tabular}{|c|l|c|}
\hline Treatment & \multicolumn{1}{|c|}{$\begin{array}{c}\text { Population arrangement } \\
(\mathrm{m})\end{array}$} & $\begin{array}{c}\text { Population } \\
\text { density } \\
\text { (plants/ha) }\end{array}$ \\
\hline 1 & Control $(2.7 \times 2.7)$ & 1,700 \\
\hline 2 & Triangle $(2.3 \times 2.3)$ & 2,000 \\
\hline 3 & Triangle $(2.15 \times 2.15)$ & 2,500 \\
\hline 4 & Triangle $(1.95 \times 1.95)$ & 3,000 \\
\hline 5 & Triangle $(1.8 \times 1.8)$ & 3,500 \\
\hline 6 & Rectangle $(3.2 \times 1.57)$ & 2,000 \\
\hline 7 & Rectangle $(2.8 \times 1.30)$ & 2,500 \\
\hline 8 & Rectangle $(2.6 \times 1.20)$ & 3,000 \\
\hline 9 & Rectangle $(2.4 \times 1.15)$ & 3,500 \\
\hline 10 & Double rows $\left(\mathrm{dp}{ }^{*} 1.0 \mathrm{~m} \times \mathrm{dr}^{* *} 3.3\right)$ & 2,000 \\
\hline 11 & Double rows $\left(\mathrm{dp} 1.2 \mathrm{~m} \times \mathrm{dr}^{* *} 3.3\right)$ & 2,500 \\
\hline 12 & Double rows $\left(\mathrm{dp} 1.0 \times \mathrm{dr}^{*} 3.0\right)$ & 3,000 \\
\hline 13 & Double rows $\left(\mathrm{dp} 1.0 \mathrm{~m} \times \mathrm{dr}^{2.8}\right)$ & 3,500 \\
\hline
\end{tabular}

${ }^{*} \mathrm{dp}$ : distance between plants; ${ }^{* *} \mathrm{dr}$ : distance between rows.

This study was established with a randomized complete block design and a $3 \times 4+1$ factorial arrangement, where the first factor corresponded to the population arrangement (rectangle, triangle and double row), the second factor was planting densities $(2,000,2,500,3,000$ and 3,500 plants/ha) and a relative control (1,700 plants/ha in a triangle), with three repetitions, for a total of 13 treatments. Each experiment unit consisted of a population of 26 plants 
established in an area of $120 \mathrm{~m}^{2}$, so the useful plot was in the center with 10 plants.

For each treatment, the harvest and post-harvest tasks were carried out in accordance with the quality protocols established by the marketing companies in the region: period of 12 weeks to harvest and a 35 $\mathrm{mm}$ thickness of the fruit in the second basal hand. In each treatment, four bunches from the plants located in the useful plot were selected, in which the planned determinations were made.

Were determinate physiological parameters in the different phenological phases of the crop [floral development, flowering and harvest] (Cayón, 2004) in the useful plot of each treatment, with an IRGA infrared gas exchange meter (LI-COR LI-6400XT ${ }^{\circledR}$ ). The equipment was calibrated to a $P A R$ of $1,000 \mu \mathrm{mol}$ $\mathrm{m}^{-2} \mathrm{~s}^{-1}$ and $\mathrm{CO}_{2}$ concentration of $\pm 350 \mathrm{ppm}$. The evaluated variables were: net photosynthesis $(P n$, $\left.\mu \mathrm{mol} \mathrm{mol}{ }^{-1} \mathrm{~s}^{-1}\right)$, internal $\mathrm{CO}_{2}$ concentration $\left(C_{\mathrm{i}}, \mu \mathrm{mol}\right.$ $\left.\mathrm{mol}^{-1}\right)$, stomatal conductance $\left(g_{s}, \mu \mathrm{mol} \mathrm{m} \mathrm{s}^{-1}\right)$, tran-

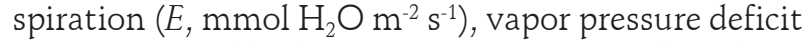
$(D P V, k P a)$ and leaf temperature $\left(T_{i}{ }^{\circ} \mathrm{C}\right)$. All readings were taken on the third leaf of the plants in relation to the flag leaf starting at 9:00 hours, when the best radiation conditions were present. Two readings were taken per day on the same plants and in each phase of the crop, for a total of four readings per week. With the recordings, the respective averages were determined. Additionally, the efficient use of water (WUE, $\left.\mu \mathrm{mol} \mathrm{CO}_{2} / \mathrm{mol} \mathrm{H}_{2} \mathrm{O}\right)$, the quantum efficiency $(\phi$, $\mathrm{mol} \mathrm{O}_{2} /$ mol photons) and the radiation use efficient $\left(\varepsilon, \mathrm{g} \mathrm{MJ}^{-1}\right)$ were determined (Solarte et al., 2010).

The bunches were harvested according to the commercial maturity point (between 10-12 weeks) based on the quality protocols established by the trader Uniban. The production was established with the bunch mass (BM; $\mathrm{kg}$ ), number of hands ( $\mathrm{HN}$; No) and number of fruits (FN; No). The quality of the fruits was based on the length of the central fruit of the last hand ( $\mathrm{LnLH} ; \mathrm{cm}$ ), degree of the central fruit of the second hand (DSH; $\mathrm{cm}$ ) and the degree of the central fruit of the last hand (DLH; $\mathrm{cm}$ ). The BM was measured on a scale, starting from the gross mass of 10 bunches per treatment; the DSH and DLH were obtained with the diameter of the fruits in the middle part in the three central fruits.

The analysis of variance (ANOVA) was used, one of which excluded the control and another that included the control. When the control was excluded, the differences between the means of the treatments represented by the population arrangements were determined with the Tukey test $(P \leq 0.05)$. To estimate the relationships between the planting densities, regression models were developed, and orthogonal contrasts were made to compare the interaction between the treatments. In the ANOVA that included the control, a randomized complete block design was used, where the treatments corresponded to the combinations of the factors and the control, which were analyzed with a Tukey test $(P \leq 0.05)$. In addition, orthogonal contrasts were developed to compare the control with the rest of the treatments. Correlation analyses were carried out between the gas exchange variables and the production variables.

\section{RESULTS AND DISCUSSION}

\section{Gas exchange}

The ANOVA of the gas exchange variables that excluded the control reported that the planting densities had an effect on $P n$ in the flowering and harvest phases, as did the interaction of the factors involved in the flowering phase $(P \leq 0.01-0.05)$. The $C_{i}$ was sensitive to the effects of the plantation density in the harvest $(P \leq 0.05)$; the same was observed for $\mathrm{E}$ in flowering ( $P \leq 0.01-0.05)$. The ANOVA that included the control showed that the spatial distribution of plants (arrangements) and densities influenced $P n$ in the flowering and harvest phases $(P \leq 0.01-0.05)$ but no differences were detected between the control and the rest of the treatments.

In the flowering phase, the double row arrangement with a population of 2,000 plants/ha reached a $P_{n}$ rate of $23.94 \mu \mathrm{mol} \mathrm{CO} \mathrm{mol}^{-1} \mathrm{~s}^{-1}$, while in the other arrangements, a decreasing trend was evident (Tab. 2). With the densities of 2,500 and 3,000 plants/ha, there were no differences between the population arrangements. This resulted from the fact that the leaf area facilitated a greater interception of radiation (Tab. 2). In addition, the triangle arrangement contributed to the increase in $P n$ when combined with a high density because of the increase in the leaf area (LA) and LAI, variables that favored the interception of PAR. On the contrary, the same condition in the rectangle arrangement saw a decrease in the $P n$, possibly associated with the greater overlap of the leaves because of the short distance between the plants located in the furrows that promoted greater intraspecific 
competition, as expressed by Rodriguez et al. (2007). However, the distribution of plants in the triangle arrangement contributed to a greater $P A R$ interception by associating it with photosynthesis when density increased (Tab. 2). The double row arrangement with the increase in density showed, in general, that $P n$ was higher than in the rectangle arrangement and stable with the lower densities, probably because of a greater penetration of light laterally to the plants (Tab. 2). The $P n$ rates in the flowering and harvest phases were higher than those mentioned for banana cultivation by Eckstein and Robinson (1995), Galán and Robinson (2013) and Rodríguez et al. (2007), who observed significant effects with increasing planting densities.

In the flowering phase, the $P n$ was explained by a quadratic model $\left(R^{2}=0.78\right)$, where the maximum value $\left(18.94 \mu \mathrm{mol} \mathrm{CO} \mathrm{mol}^{-1}\right)$ was recorded with the density of 2,500 plants/ha, noting a reduction for the higher densities (Fig. 1A). It is possible that the behavior of $P n$ as a function of plant density was also influenced by the spatial distribution of plants and other environmental variables, such as temperature and cloudiness, which may explain the $R^{2}$ in the model. However, starting at 2,500 plants/ha, the photosynthetic activity was disadvantaged, an aspect that was directly related to the variables of $\mathrm{E}$ and $C_{i}$. This led to the inference that, as a result of overlapping leaves, which was more accentuated with the increasing densities, there was probably a decrease in the transpiration rates, a process that influenced the gas exchange rates, affecting the $C_{i}$, an essential input for Rubisco enzymatic activity, a fundamental enzyme for photosynthesis (Parry et al., 2013). A decrease in $\mathrm{Pn}$ with increasing planting densities, according to Siles et al. (2013), is due to the increase in the shading level, which causes lower solar interception in the lower leaf strata. Cayón (2001) maintained that there are other factors that influence $P n$, such as the age of the leaf, which is related to the development phase, generating changes in the internal concentration of $\mathrm{CO}_{2}$, the activity of Rubisco and the electron transport chain.

The $P n$ and $E$ in the flowering phase and the As for the $C_{i}$ in the harvest phase were expressed by the quadratic models $\left(R^{2}=0.73\right.$ and 0.71$)$ (Fig. 1, B and C). The behavior of $P n$ and $E$ at the low densities confirmed the relationship between these variables with increases or decreases densities occasioned by existing radiation and humidity conditions caused by changes in the number of plants and their different arrangements, that influence stomatal conductance and internal $\mathrm{CO}_{2}$ concentration $\left(C_{i}\right)$ (Fig. $1, \mathrm{~B}$ and $\mathrm{C}$ ). The results obtained for the lowest densities are in line with those of Liu et al. (2019), who stated that a decrease in $C_{i}$ is likely due to an increase in $P n$, which causes a greater assimilation of $\mathrm{CO}_{2}$. Likewise, a positive correlation was observed between these variables since both processes depend on stomatal opening and closing, which regulate the flow of $\mathrm{CO}_{2}$ and water vapor (Enginneer et al. 2016; Cayón, 2001).

The analysis of variance that excluded the control showed that the WUE and $\phi$ responded to the planting density in the flowering and harvest phase, respectively. The analysis of variance that included the control showed significant differences between the treatments in the flowering phase for the variables indicated above; however, for the flowering $\phi$, differences were detected between the control and the average of the rest of the treatments.

In the flowering phase, the WUE was represented by a quadratic model $\left(R^{2}=0.91\right)$, observing that this variable decreased with increasing planting densities (Fig. 2A); the results allowed the inference that the density of 2,500 plants/ha offered a greater advantage in the WUE, while the low density of 1,700 and high density of 3,000 plants/ha require a greater use of water for biomass production. Related studies by

Table 2. Pn response depending on the population arrangement and planting density in the flowering phase in banana cv. Williams (Musa AAA Simmonds).

\begin{tabular}{|c|c|c|c|c|}
\hline \multirow{2}{*}{$\begin{array}{c}\text { Population } \\
\text { arrangement }\end{array}$} & 2,000 & 2,500 & 3,000 & 3,500 \\
\cline { 2 - 5 } & $19.27 \mathrm{~B} \mathrm{ab}$ & $14.31 \mathrm{~A} \mathrm{c}$ & $17.52 \mathrm{~A} \mathrm{bc}$ & $22.91 \mathrm{Aa}$ \\
\hline Triangle & $20.05 \mathrm{AB} \mathrm{a}$ & $17.14 \mathrm{~A} \mathrm{ab}$ & $14.15 \mathrm{~A} \mathrm{bc}$ & $12.07 \mathrm{C} \mathrm{c}$ \\
\hline Rectangle & $23.94 \mathrm{~A} \mathrm{a}$ & $15.84 \mathrm{~A} \mathrm{~b}$ & $17.01 \mathrm{~A} \mathrm{~b}$ & $17.75 \mathrm{Bb}$ \\
\hline Double rows & &
\end{tabular}

Means with the same lowercase letter in the rows do not differ statistically according to the orthogonal contrasts $(P \leq 0.05)$. 


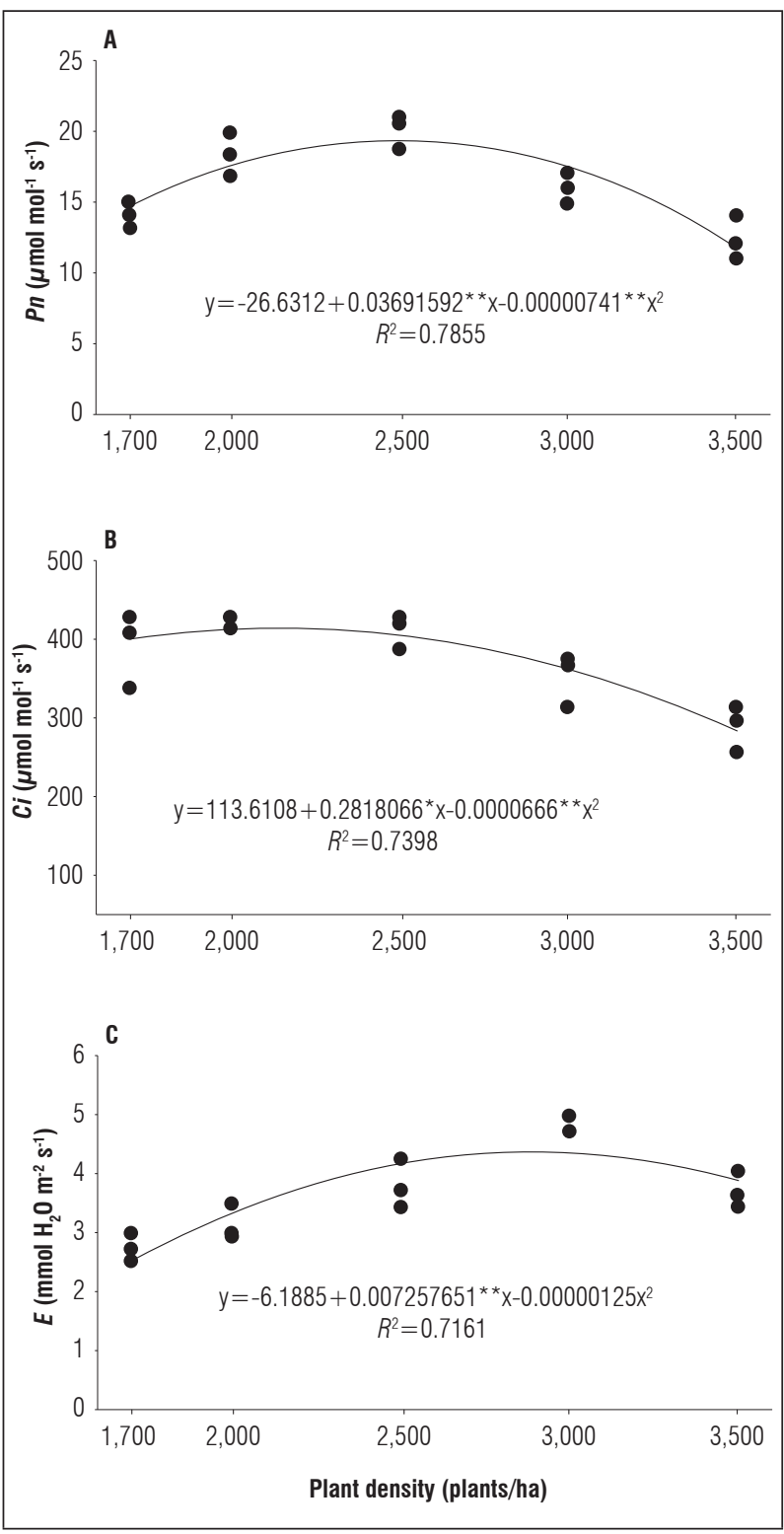

Figure 1. Response of $P n, C_{i}$ and $E$ as a function of population density: a) $P n$ in flowering, b) $C_{i}$ at harvest; c) $E$ in flowering banana cv. Williams (Musa AAA Simmonds).

Arantes et al. (2016) evidenced that, for different banana clones, the effects varied during the day. Cayón (2001) pointed out that $P n$ and $E$ are positively correlated, and that their efficiency is concordant with the ontogeny of the foliar system. Lawson and Blatt (2014) clarified that $P n$ and $E$ depend directly on WUE, a physiological process that in turn is linked to the dynamics of opening and closing of stomata because these structures regulate the flow of $\mathrm{CO}_{2}$ and water

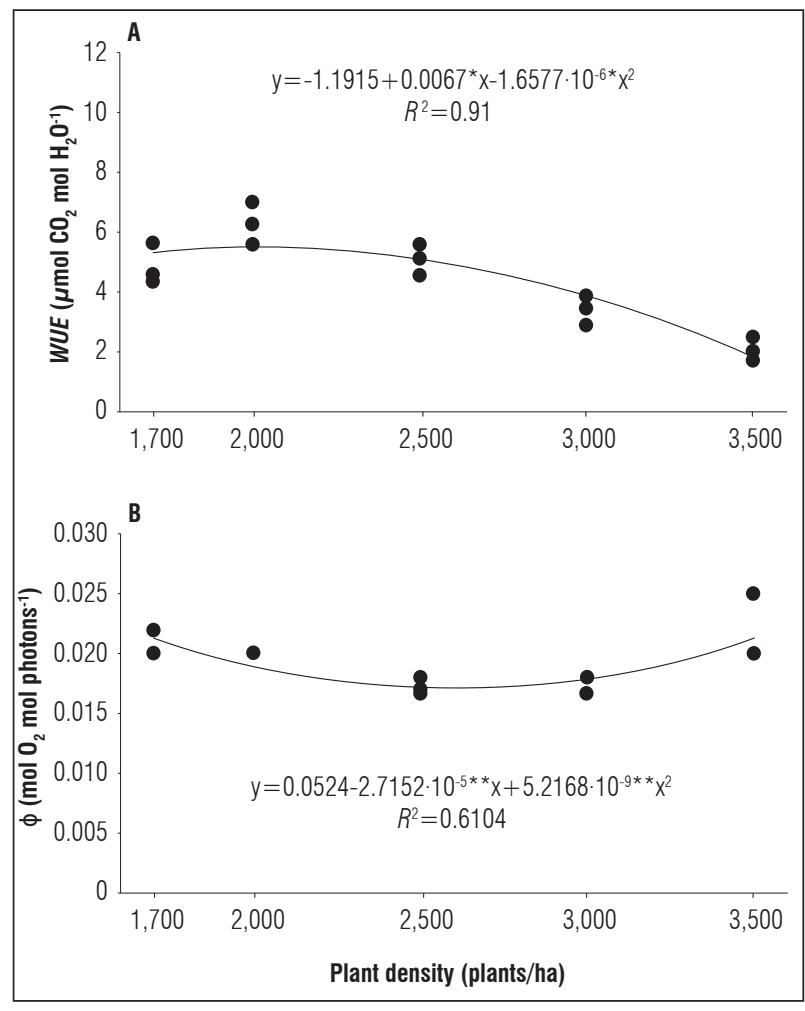

Figure 2. WUE and $\phi$ response as a function of population density in banana cv. Williams (Musa AAA Simmonds): a) WUE at flowering; b) $\phi$ at harvest.

vapor and, therefore, directly affect $P n$. It is important to highlight that the plantation densities generated environmental conditions that contributed to increasing photosynthesis in an attempt to improve the productivity of the banana crop.

The triangle arrangement generally favored the $\phi$ more than the other treatments; however, the double row arrangement also supported the latter (Tab. 2). These variables are important from the agronomic point of view for cultivation systems with high densities and irrigation systems; these data can be used as a reference point and are consistent with those indicated by Barrera et al. (2020) where the triangle distribution contributed to a greater bunch mass gain without affecting the exportable quality. The proposed values are similar to those of Santos et al. (2015) for the cultivation of bananas. The increase in densities was expected to improve the WUE because of the greater overlap of leaves that directly decreases temperature (Santos et al., 2015). An increase in production is expected with increased planting densities because a greater foliar area influences a greater 
interception in PAR (Rodríguez et al., 2007; Athani et al., 2009; Smith et al., 2010).

The $\phi$ was represented with a quadratic model that had an $R^{2}=0.6104$ (Fig. 2B), probably associated with other factors that intervene in the conversion of energy into biomass. Similar research has indicated that the evaluations carried out to measure the gas exchange were punctual values and were influenced by climatic conditions (Santos et al., 2015), not considered in the study. The $\phi$ decreased as the planting density increased, a trend that changed starting at 2,500 plants/ha (Fig. 2B). The initial indications were very likely due to the increase in transpiration rates generated by the increase in the number of plants and the mutual shading between the plants. The observations for the high densities could have been based on the need of the plants to make morphological couplings as a result of the low light intensity, a limitation that is compensated for with a larger leaf area as a strategy to increase the photosynthetic surface and improve the energy collection process (Jaramillo et al., 2009). The results indicated that the double row distribution (Tab. 2), in which the plants better intercepted the solar radiation and made use of it, which confirmed the observations of Cayón (2004) and Rodríguez et al. (2007), stressing that, in crops planted in rows, the greater penetration of light into the canopy and the degree of absorption of the incident PAR depend on the distances between rows and plants and the planting arrangement. Furthermore, the results are consistent with the report by Rocha et al. (2018) for banana 'Prata' and by Santoset al. (2015) for banana 'BRS Princesa'. The data also indicated that the $P n$ and $E$ were directly correlated with the $g_{s}, W U E$ and $T_{i}$, while the WUE and $P n$ were inversely

Table 3. Pearson's correlation between the variables of gas exchange and production in banana cv. Williams (Musa AAA Simmonds) in the triangle, rectangle and double row population arrangements in the flowering phase.

\begin{tabular}{|c|c|c|c|c|c|c|c|}
\hline Arrangement & Variables & BM & NH & NF & LnLH & DSH & DLH \\
\hline \multirow{8}{*}{ Triangle } & $P n$ & $-0,03$ & 0,14 & $-0,05$ & $-0,17$ & $-0,12$ & $-0,41$ \\
\hline & $g_{s}$ & 0,29 & $-0,08$ & $-0,03$ & 0,27 & 0,04 & 0,04 \\
\hline & $C_{i}$ & 0,16 & $-0,13$ & $-0,30$ & $-0,05$ & $-0,05$ & 0,37 \\
\hline & $E$ & 0,35 & $-0,32$ & $-0,30$ & 0,27 & 0,32 & $0,57^{*}$ \\
\hline & $D P V$ & $-0,12$ & 0,00 & $-0,22$ & $-0,31$ & 0,18 & 0,07 \\
\hline & $T_{i}$ & 0,00 & 0,11 & $-0,16$ & $-0,18$ & 0,22 & $-0,03$ \\
\hline & $P n / E$ & 0,28 & 0,21 & 0,12 & $-0,53^{*}$ & $-0,38$ & $-0,58^{*}$ \\
\hline & $P n / R F A$ & 0,04 & 0,00 & 0,08 & 0,05 & $-0,23$ & $-0,48$ \\
\hline \multirow{7}{*}{ Rectangle } & $P n$ & $0,58^{*}$ & $-0,02$ & $-0,06$ & 0,44 & $0,66^{*}$ & $0,61^{*}$ \\
\hline & $g_{s}$ & $-0,34$ & $-0,03$ & $-0,10$ & 0,10 & $-0,13$ & $-0,06$ \\
\hline & $C_{i}$ & $-0,08$ & 0,14 & 0,00 & 0,02 & $-0,14$ & $-0,02$ \\
\hline & $E$ & $-0,45$ & $-0,30$ & $-0,48$ & 0,23 & 0,09 & 0,31 \\
\hline & $D P V$ & $-0,06$ & $-0,13$ & $-0,18$ & 0,02 & $-0,03$ & 0,16 \\
\hline & $P n / E$ & $0,64^{*}$ & 0,22 & 0,24 & 0,08 & 0,38 & 0,22 \\
\hline & $P n / R F A$ & $-0,21$ & $-0,21$ & $-0,13$ & 0,49 & 0,57 & 0,52 \\
\hline \multirow{7}{*}{ Doble row } & $P n$ & $-0,25$ & $-0,26$ & $-0,01$ & $-0,06$ & $-0,60^{*}$ & $-0,50$ \\
\hline & $g_{s}$ & $0,60^{*}$ & 0,30 & 0,49 & 0,26 & 0,29 & $-0,14$ \\
\hline & $C_{i}$ & 0,22 & 0,13 & 0,07 & 0,14 & 0,23 & $-0,46$ \\
\hline & $E$ & 0,49 & 0,29 & 0,31 & 0,25 & 0,12 & $-0,29$ \\
\hline & $D P V$ & $-0,50$ & $-0,35$ & $-0,46$ & $-0,03$ & $-0,34$ & 0,06 \\
\hline & $P n / E$ & $-0,50$ & $-0,32$ & $-0,15$ & $-0,22$ & $-0,50$ & $-0,01$ \\
\hline & PnRFA & $-0,25$ & $-0,25$ & $-0,02$ & $-0,16$ & $-0,49$ & $-0,61^{*}$ \\
\hline
\end{tabular}

BM: Bunch mass; NH: Number of hands; NF: Number of fruits; LnLH: Length of the last hand; DSH: Second hand grade; DLH: Last hand grade; *: Significant differences at $5 \%(P \leq 0.05)$. 
associated with the $E$ and $T_{\mathrm{i}}$ (Tab. 3), which is in line with the statements by Urban et al. (2017) that $g_{s}$ directly modifies water relations and photosynthesis and by Gariglio et al. (2007) that the amount of water that plants use and transpire depends on the species and the changing environmental conditions.

\section{Correlation between the variables of gas exchange and production}

In the floral differentiation phase, there were no positive correlations between the production variables and field arrangement. It is possible that, at this phase of development, the pressure exerted by the densities and decreased leaf overlap did not influence the physiological response of the plants. Furthermore, the metabolic activity of leaves during the floral differentiation phase is high (Vargas-Calvo et al., 2015).

In the flowering phase with the triangle arrangement, the $\mathrm{E}$ was positively correlated with the variable DLH (Tab. 3). Higher transpiration rates mean more possibilities to increase $g_{s}$ because of greater stomatal opening, which is associated with higher $P n$ rates, as long as the environmental conditions oscillate in the ranges required for $\mathrm{C} 3$ plants, such as bananas (Ainsworth and Rogers, 2007). The aforementioned conditions favor the availability of assimilates to fill bunches; however, in C3 plants, the use of water is not very efficient because $\mathrm{CO}_{2}$ capture is done at the cost of large deliveries of water to the atmosphere (Qaderi et al., 2019). On the other hand, Gariglio et al. (2007) argued that $E$ is associated with increased production, while Runkle (2015) stated that internal $\mathrm{CO}_{2}$ concentrations are favored by high levels of radiation and moderate or warmer temperatures.

The correlation of $E$ with LnLH indicates that photosynthesis rates are associated with transpiration rates, which contribute to fruit filling, while photosynthetic efficiency can be affected by the degree of leaf exposure and the ability to intercept solar radiation (Tab. 3), which is consistent with the findings of Coelho et al. (2006), who indicated that water demand and crop productivity tend to increase linearly with $E$, which negatively affects the correlation of WUE with LnLH and DLH by increasing densities or changing distribution. These results are consistent with those indicated by Rodríguez et al. (2007), who reported that high banana plantation densities intercept a higher proportion of $P A R$, which can exceed $90 \%$ of the incident radiation because of the increase in LAI, a product of the planting density, obtaining lighter bunches. Thippesha et al. (2008) stated that, by reducing the distance between banana plants, the intensity of light available for the middle and lower strata of the plant is decreased, even with a low $P_{n}$, without affecting production per plant and time to flowering because the assimilated demand is supplied by the individual photosynthetic efficiency of the most exposed leaves, a process that benefits from the reduction in the temperature inside the canopy by making enzymatic processes more efficient.

In the rectangular arrangement, the $P n$ was positively correlated with the variables $\mathrm{BM}, \mathrm{DSH}$, and $\mathrm{DLH}$. (Tab. 3). The data marked the effect of the arrangements on the gas exchange variables since, the higher the $P n$ is, the higher the production of assimilates is, the higher the profit in the $\mathrm{BM}$ is, and the greater the filling of the hands is. The dependence observed in the variables was largely due to the changes generated by the spatial arrangements and population densities that influenced the magnitude of the incident PAR in the leaf strata and the intensity of the temperature on the photosynthetic surfaces despite the lack of significant effects on the thermal level of the leaves, which was pointed out by Santos et al. (2015), noting that increases in leaf temperature increase transpiration and reduce efficiency in the use of water and could also be associated with changes in photosynthesis because of variations in temperature, as highlighted by Hermida-Carrera et al. (2016) when stating that the thermal dependence of Rubisco's catalytic activity is a factor that limits the $\mathrm{CO}_{2}$ assimilation potential of plants.

In the double row arrangement, the $P n$ presented negative correlations with all the variables, while the $g_{s}$ and the $E$ had a negative correlation with the DLH variable (Tab. 3). The relationships corresponded with the conditions generated in the different treatments as a result of the variations in the environment caused by the distribution of the plants in the different densities, with the magnitudes of each of the variables affected to different degrees. For example, by improving the interception of radiation with the arrangement of the leaves, the bunch filling increased, particularly with the lower densities, which favored the use of the photoassimilates by the fruits. Likewise, by generating conditions that favored higher photosynthesis rates, the VPD increased, with a consequent effect on the $\mathrm{CO}_{2}$ exchange rate and a lower contribution of assimilates for the fruits. This situation was evident during the development of the 
study, particularly in treatments with high plant densities, in which high transpiration rates and variations in other environmental variables occurred. Studies on this subject have discussed the relationship between photosynthesis and gas exchange with the production of assimilates, without neglecting the availability of water, a fundamental element in the soil-plant-atmosphere relationship (Landsberg and Waring, 2017).

In the harvest phase with the triangle arrangement, the $P n$ had a positive correlation with the variables
$\mathrm{BM}, \mathrm{HN}$ and DSH. A similar association was observed when the $E$ and $C_{i}$ were compared with the variables $\mathrm{BM}, \mathrm{DSH}$ and DLH; while the WUE was negatively correlated with the LnLH and DLH (Tab. 4). When the treatments considered the low densities, the $\mathrm{CO}_{2}$ exchange rates increased, improving the plants' biochemical processes, such as photosynthesis, as reflected in greater filling of the bunches and hands, as evidenced for the density 2,000 plants/ha (Tab. 2). On the other hand, the increase in planting densities influenced higher transpiration rates and a decrease in incident radiation inside the cultivation system,

Table 4. Pearson's correlation between the variables of gas exchange and production in banana cv. Williams (Musa AAA Simmonds) in the triangle, rectangle and double row population arrangement in the harvest phase.

\begin{tabular}{|c|c|c|c|c|c|c|c|}
\hline Arrangement & Variables & BM & NH & NF & LnLH & DSH & DLH \\
\hline \multirow{9}{*}{ Triangle } & $P n$ & 0.39 & 0.24 & -0.08 & -0.16 & 0.09 & -0.09 \\
\hline & $g_{s}$ & -0.12 & 0.08 & -0.20 & -0.11 & -0.08 & 0.44 \\
\hline & $C_{i}$ & 0.23 & -0.07 & -0.29 & -0.02 & 0.28 & $0.57^{* *}$ \\
\hline & $E$ & 0.10 & 0.00 & -0.22 & -0.04 & 0.07 & 0.48 \\
\hline & $V P D$ & 0.09 & -0.09 & 0.06 & 0.32 & -0.03 & -0.20 \\
\hline & $T_{i}$ & 0.30 & 0.15 & 0.22 & 0.35 & -0.10 & -0.23 \\
\hline & WUE & -0.28 & 0.21 & 0.12 & $-0.53^{*}$ & -0.38 & $-0.58^{*}$ \\
\hline & $\phi$ & 0.04 & 0.00 & 0.08 & 0.05 & -0.23 & -0.48 \\
\hline & $\varepsilon$ & $0.78^{* *}$ & -0.42 & -0.34 & 0.19 & 0.20 & $0.55^{*}$ \\
\hline \multirow{9}{*}{ Rectangle } & $P n$ & -0.14 & -0.49 & -0.42 & 0.39 & 0.19 & 0.40 \\
\hline & $g_{s}$ & 0.42 & 0.19 & -0.04 & -0.08 & $0.68^{*}$ & 0.47 \\
\hline & $C_{i}$ & 0.36 & -0.13 & 0.08 & 0.11 & 0.43 & 0.18 \\
\hline & $E$ & 0.29 & 0.16 & -0.10 & -0.07 & $0.62^{*}$ & 0.49 \\
\hline & VPD & -0.46 & -0.45 & -0.16 & 0.38 & -0.55 & -0.27 \\
\hline & $T_{i}$ & -0.55 & -0.53 & -0.26 & 0.44 & -0.54 & -0.23 \\
\hline & WUE & -0.55 & -0.53 & -0.26 & 0.44 & -0.54 & -0.23 \\
\hline & $\phi$ & -0.41 & -0.43 & -0.20 & 0.32 & -0.47 & -0.20 \\
\hline & $\varepsilon$ & 0.45 & -0.54 & -0.21 & 0.33 & 0.36 & -0.42 \\
\hline \multirow{9}{*}{ Double row } & $P n$ & -0.30 & -0.18 & -0.29 & 0.08 & -0.12 & 0.27 \\
\hline & $g_{s}$ & -0.55 & -0.39 & -0.42 & -0.35 & -0.47 & -0.46 \\
\hline & $C_{i}$ & -0.34 & -0.09 & -0.38 & -0.26 & 0.05 & -0.25 \\
\hline & $E$ & -0.08 & -0.16 & -0.34 & 0.07 & 0.15 & -0.52 \\
\hline & $V P D$ & 0.02 & 0.39 & 0.36 & -0.20 & -0.07 & $0.64^{*}$ \\
\hline & $T_{i}$ & -0.24 & 0.26 & 0.21 & -0.22 & -0.11 & $0.66^{*}$ \\
\hline & WUE & -0.24 & 0.26 & 0.21 & -0.22 & -0.11 & $0.66^{*}$ \\
\hline & $\phi$ & -0.03 & 0.08 & 0.12 & 0.17 & -0.03 & $0.73^{* *}$ \\
\hline & $\varepsilon$ & $0.67^{*}$ & $0.70^{*}$ & $0.86^{* *}$ & 0.00 & -0.18 & 0.26 \\
\hline
\end{tabular}

BM: Bunch mass; NH: Number of hands; NF: Number of fruits; LnLH: Length of the last hand; DSH: Second hand grade; DLH: Last hand grade; *: Significant differences at $5 \%(P \leq 0.05){ }^{* *}$ : Significant differences at $1 \%(P \leq 0.01)$. 
making the WUE and photosynthetic processes less effective, conditions that negatively affected bunch filling and manifested the lowest BM observed in the higher densities. Senevirathna et al. (2008) stated that net $\mathrm{CO}_{2}$ assimilation rates generally decrease with low radiation, but that the specific area of the leaf and the ratio of the leaf area increase proportionally with decreasing energy levels from the sun, while the chlorophyll $a / b$ ratio decreases, reflecting greater efficiency in the use of light under shady conditions. On the contrary, Siles et al. (2013) and Rocha et al. (2017) argued that exposure to full radiation in banana crops increases yield but clarified that net photosynthesis curves vary and other biochemical parameters of photosynthesis are affected by shading and temperature conditions of the leaf.

Finally, the $\varepsilon$ was positively correlated with the variables BM, LnLH, and DLH (Tab. 4). In the harvest phase, the leaf age is advanced, so photosynthetic and transpiration processes are affected by the drop in chlorophyll content. These results agree with the observations of Cayón et al. (2004), who argued that there is a positive relationship between $P_{n}, E$ and chlorophyll content in any phase of leaf development, and of Cayón (2001), who pointed out that changes occur in the phyllotaxis of leaves as development progresses, affecting the exposure of the leaf blade to radiation; however, Rodríguez et al. (2007) did not report effects on the insertion angle of the leaf from an increase in densities and population arrangements. Likewise, shady conditions can influence the aqueous balance of the stomatal cavity, as reflected in the turgidity of the guard cells and the opening of the stomata, with directly affects $P n$ and other associated metabolic processes (Lawson and Blatt, 2014).

In the rectangular arrangement, the $P n$ had a positive correlation with the variables $\mathrm{LnLH}, \mathrm{DSH}$ and $\mathrm{DLH}$; the same dependency was registered between the $g_{s}$ and the variables BM, HN, DSH and DLH; likewise, the $\varepsilon$ depended on the variables BM, $\mathrm{LnLH}, \mathrm{DSH}$ and $\mathrm{DLH}$ (Tab. 4). In the BM variable, the correlation with the $P n$ was antagonistic with respect to the correlations of the variables $g_{s}$ and $E$. This was explained by the fact that these processes are inclusive of each other, and their magnitudes increased or decreased proportionally in such a way that the positive correlations contributed assimilates to bunch filling; however, when VPD is high, stomatal closure occurs, which is reflected in falls in $P n$. This is similar to that reported by Huntingford et al. (2015) for correlations between variables associated with $g_{s}$, such as $D P V$ and $P n$. These results indicated that the photosynthetic activity of the banana plants was variable and conditioned by the spatial arrangements of the treatments. Santosh et al. (2017) indicated that climatic conditions change the water content of plants, gas exchange, and leaf temperature, variations that influence growth, development, and production. Moreover, Magnabosco and Cardin (2018) indicated that the photosynthesis rate of a leaf depends on multiple individual factors, each of which presents its own response to each environmental variable. Lanuakum et al. (2015) suggested that a negative relationship between canopy temperature and other performance attributes, such as temperature and plant density, influence banana productivity. Further, other related studies have indicated that planting densities and plant distribution influence the productivity of the banana crop (Rodriguez et al. 2007; Barrera et al., 2020).

In the double row arrangement, the VPD was positively correlated with the variables BM, HN, FN and DHL; the same was repeated for the variable $\varepsilon$ (Tab. 4). The relationships showed that the low planting densities favored higher transpiration rates, which contributed positively to the increase in photosynthesis rates and a greater mass gain in BM, which is why these densities were considered more efficient. On the contrary, when the densities increased although there was greater interception of radiation, this fact was not reflected in the bunch size because the conditions generated by the competition between the plants and overlapping leaves affected the photosynthetic efficiency of the plants, as reflected in the low WUE. Lanuakum et al. (2015) reported high correlation coefficients in most of the studied characteristics, which was associated with the influence of solar radiation on the best crop yield. Therefore, by increasing planting densities, the exposure of leaves to light and the degree of insertion of these are modified until they are partially shaded, which somehow reduces $P_{n}$ and $E$, affecting the balance of gas exchange in the plant (Cayón, 2001), which affects $\varepsilon$. Finally, these results agree with those of Hatfield and Dold (2019), who pointed out that this process affects an increase in the $\mathrm{CO}_{2}$ inside leaves in the presence of adequate levels of radiation and temperature, which normally cause an increase in photosynthetic rates and improve $\varepsilon$.

It was determined that the arrangement of the plants played an important role in the $P n$; in addition, the triangle arrangement favored the variables associated 
with this process more. These results coincide with those reported by Surendar et al. (2015), who argued that the correlation between the number of leaves, the total chlorophyll content and the relative water content with yield is positive and significant. Santos et al. (2015) noted that increases in $E$ rates are associated with growth in $P n$ rates, which leads to increases in production.

\section{CONCLUSIONS}

Banana cultivation cv. Williams (Musa AAA Simmonds) with a density of 2,500 plants/ha and arranged in a triangle or double rows, makes more efficient use of climate elements associated with photosynthetic activity under the environmental conditions of Uraba, Antioquia, an aspect that is positively reflected in the productivity and quality of fruits.

An increase in the number of plants and incorporation of alternatives for spatial field distribution are viable options for balancing harvest with variations in the availability of rain throughout the year, improving the income of farmers.

Conflict of interests: The manuscript was prepared and reviewed with the participation of the authors, who declare that there exists no conflict of interest that puts at risk the validity of the presented results.

\section{BIBLIOGRAPHIC REFERENCES}

Ainsworth, E.A. and A. Rogers. 2007. The response of photosynthesis and stomatal conductance to rising $\left[\mathrm{CO}_{2}\right]$ : mechanisms and environmental interactions. Plant Cell Environ. 30, 258-270. Doi: 10.1111/j.1365-3040.2007.01641.x

Arantes, A., S. Rodrigues, E. De Siqueira, Coelho, and T. Silva. 2016. Gas exchange in different varieties of banana prata in semi-arid environment. Rev. Bras. Frutic. 38(2), 1-12. Doi: 10.1590/0100-29452016600

Athani, S., I. Revanappa, and P.R. Dharmatti. 2009. Effect of plant density on growth and yield in banana. Karnataka J. Agric. Sci. 22(1), 143-146.

AUGURA, Asociación de Bananeros de Colombia. 2017. Coyuntura bananera colombiana. Unidad de Estadística y Análisis Económico. Medellin, Colombia.

AUGURA, Asociación de Bananeros de Colombia. 2018. Coyuntura bananera colombiana. Unidad de Estadística y Análisis Económico. Departamento de Sistemas. Medellin, Colombia.
Barrera, J., J. Cartagena, and O. Nanclares. 2020. Influence of high planting densities and arrangements on yield and fruit development of Musa AAA Simmonds. Acta Agron. 69(1), 46-53. Doi: 10.15446/acag.v69n1.79834

Benson, A. 2013. Influence of number of sucker per plant on the growth, yield and yield components of plantain (Musa sp.) in Ado-Ekiti, Nigeria. Agric. Sci. Res. J. 3(2), 45-49.

Cayón, G. 2001. Evolución de la fotosíntesis, transpiración y clorofila durante el desarrollo de la hoja de plátano (Musa AAB Simmonds). Infomusa 10(1), 12-15.

Cayón, G. 2004. Ecofisiología y productividad del plátano (Musa AAB Simmonds). pp. 172-183. In: Proc. XVI Reunión de la Asociación para la Cooperación en Investigaciones de Banano en el Caribe y en América Tropical. ACORBAT, Oaxaca, México.

Cayón, G., J.A. Valencia, H. Morales, and A. Domínguez. 2004. Desarrollo y producción del plátano Dominico-Hartón (Musa AAB Simmonds) en diferentes densidades y arreglos de siembra. Agron. Colomb. 22(1), 18-22.

Coelho, E., E. da Costa, C. da Silva, and S. de Oliveira. 2006. Produtividade e eficiência do uso de água das bananeiras 'Prata Anã' e 'Grand Naine' sob irrigação no terceiro ciclo no Norte de Minas Gerais. Irriga 11(4), 460-468. Doi: 10.15809/irriga.2006v11n4p460-468

Eckstein, K. and J.C. Robinson. 1995. Physiological responses of banana (Musa AAA; Cavendish subgroup) in the subtropics. (I) Influence of internal plant factors on gas exchange of banana leaves. J. Hortic. Sci. 70, $147-$ 156. Doi: 10.1080/14620316.1995.11515284

Enginneer, C., M. Hashimoto-Sugimoto, J. Negi, M. Israelsson-Nordstrom, T. Azoulay-Shemer, W.J. Rappel, K. Iba, and J. Schroeder. 2016. $\mathrm{CO}_{2}$ sensing and $\mathrm{CO}_{2}$ regulation of stomatal conductance: advances and open questions. Trends Plant Sci. 21(1), 16-30. Doi: 10.1016/j.tplants.2015.08.014

FAO. 2020. Banana market review: Preliminary results 2019. Roma.

Galán, V. and J. Robinson. 2013. Fisiología, clima y producción de banano. pp. 43-57. In: Proc. XX Reunião Internacional da Associação para a Cooperação em Pesquisa e Desenvolvimento Integral das Musáceas (Bananas e Plátanos). Fortaleza, Brazil.

Gariglio, N., R. Pilatti, and M. Fonfría. 2007. Requerimientos ecofisiológicos de los árboles frutales. pp. 41-82 In: Sozzi, G.O. (ed.). Árboles frutales. Ecofisiología, cultivo y aprovechamiento. Buenos Aires, Argentina: Editorial Facultad de Agronomía, Universidad de Buenos Aires.

Hatfield, J.L. and C. Dold. 2019. Water-use efficiency: advances and challenges in a changing climate. Front. Plant Sci. 10, 103. Doi: 10.3389/fpls.2019.00103 
Hermida-Carrera, C., M.V. Kapralov, and J. Galmés. 2016. Rubisco catalytic properties and temperature response in crops. Plant Physiol. 171(4), 2549-256. Doi: 10.1104/pp.16.01846

Huntingford, C., D. Mark, W. Davies, R. Falk, R. Sitch, and L. Mercado. 2015. Combining the [ABA] and net photosynthesis-based model equations of stomatal conductance. Ecol. Model. 300, 81-88. Doi: 10.1016/j. ecolmodel.2015.01.005

IGAC, Instituto Geográfico Agustín Codazzi. 2007. Estudio semidetallado de los suelos de las áreas potencialmente agrícolas: Urabá, departamento de Antioquia. Bogota.

Jaramillo, C., M. Oliva, and R. Ferreira. 2009. Respuesta fotosintética de diferentes ecotipos de fríjol a la radiación y la salinidad. Corpoica Cienc. Tecnol. Agropecu. 10(2), 129-140. Doi: 10.21930/rcta.vol10_num2_art:135

Landsberg, J. and R. Waring. 2017. Water relations in tree physiology: where to from here? Tree Physiol. 37(1), 18-32. Doi: 10.1093/treephys/tpw102

Lanuakum, G., I. Yepthomi, and C. Maiti. 2015. Effect of radiation interception and canopy temperature on growth, yield and quality in banana cv. Grande naine (AAA) under different planting densities. J. Hortic. Sci. 10(2), 172-176.

Lawson, T. and M.R. Blatt. 2014. Stomatal size, speed, and responsiveness impact on photosynthesis and water use efficiency. Plant Physiol. 1664, 1556-1570. Doi: 10.1104/pp.114.237107

Liu, X., H. Zhang, J. Wang, X. Wu, S. Ma, Z. Xu, T. Zhou, N. $\mathrm{Xu}, \mathrm{X}$. Tang, and B. An. 2019. Increased $\mathrm{CO}_{2}$ concentrations increasing water use efficiency and improvement PSII function of mulberry seedling leaves under drought stress. J. Plant Interact. 14(1), 213-223. Doi: 10.1080/17429145.2019.1603405

Magnabosco, F. and F. Cardin. 2018. A qualitative dynamic picture of the chemical kinetics for photosynthesis. Atti Accad. Pelorit. Pericol. Cl. Sci. Fis. Mat. Nat. 96, S3, A5.

Parry, M., P.J. Andralojc, J.C. Scales, M.E. Salvucci, A.E. Carmo-Silva, H. Alonso, and S.M. Whitney. 2013. Rubisco activity and regulation as targets for crop improvement. J. Exp. Bot. 64(3), 717-730. Doi: 10.1093/ jxb/ers336

Patil, P., P. Biradar, A. Bhagawathi, and I. Hejjegar. 2018. A review on leaf area index of horticulture crops and its importance. Int. J. Curr. Microbiol. App. Sci. 7(4), 505513. Doi: 10.20546/ijcmas.2018.704.059

Qaderi, M.M., A.B. Martel, and S.L. Dixon. 2019. Environmental factors influence plant vascular system and water regulation. Plants 8(65), 1-23. Doi: 10.3390/ plants8030065

Ramirez, J., A. Jarvis, I. Van den Bergh, C. Staver, and D. Turner. 2011. Changing climates, effects on growing and plantain (Musa spp.) and possible responses. pp. 426-438. In: Yadav, S., R. Redden, J. Hartfield, H. Lotze-Campen, and A. Hall (eds). Crop adaptation to climate change. John Wiley and Sons, Chichester, UK. Doi: 10.1002/9780470960929.ch29

Ravi, I., S. Uma, M. Vaganan, and M. Mustaffa. 2013. Phenotyping bananas for drought resistance. Front. Physiol. 4, 1-9. Doi: 10.3389/fphys.2013.00009

Robinson, J. and V. Galán. 2010. Bananas and plantains. CABI, London. Doi: 10.1079/9781845936587.0000

Rocha, M., S. Rodrigues, A. Arantes, E. Coelho, and P. de Oliveira. 2017. Gas exchange in 'BRS Princesa' banana (Musa spp.) under partial rootzone drying irrigation in the north of Minas Gerais, Brazil. Acta Agron. 66(3), 378-384. Doi: 10.15446/acag.v66n3.55056

Rocha, P., S. Rodrigues, A. Rebouças, and R. Carriello. 2018. Gas exchange and yield of Prata-type banana plants with fertilizer sources for organic management. Afr. J. Agric. Res. 13(5), 272-280. Doi: 10.5897/ AJAR2017.12896

Rodríguez, W., J. Araya, and L. Pérez. 2007. Efecto del arreglo espacial y la densidad de siembra sobre la estructura y eficiencia del dosel, el crecimiento y la producción del banano (Musa AAA cv. Willians). Corbana 33(60), $1-14$.

Runkle, E. 2015. Interactions of light, $\mathrm{CO}_{2}$ and temperature on photosynthesis. In: Michigan State University. Extension Floriculture Team, https://www.canr.msu. edu/uploads/resources/pdfs/light-co2-and-temp.pdf; consulted: December, 2019.

Santos, A., E. Amorim, C. Ferreira, and C.P. Pirovani. 2018. Water stress in Musa spp.: A systematic review. PLoS ONE 13(12), 1-17. Doi: 10.1371/journal.pone.0208052

Santos, R., L.W. Pacheco, S. Costa, N. Machado, P.C. de Mello Farias, C. Rombaldi, and A. Costa de Oliveira. 2015. Genetic regulation and the impact of omics in fruit ripening. Plant Omics 8(2), 78-88.

Santosh, D., K. Tiwari, and R. Gopala. 2017. Banana bunch covers for quality banana production - A Review. Int. J. Curr. Microbiol. Appl. Sci. 6(7), 1275-129. Doi: 10.20546/ijcmas.2017.607.155

Senevirathna, A., C. Stirling, and V. Rodrigo. 2008. Acclimation of photosynthesis and growth of banana (Musa sp.) to natural shade in the humid tropics. Exp. Agric. 44(3), 301-312. Doi: 10.1017/S0014479708006364

Siles, P., O. Bustamante, E. Valdivia, J. Burkhardt, and C. Staver. 2013. Photosynthetic performance of banana ('Gros Michel', AAA) under a natural shade gradient. Acta Hortic. 986, 71-77. Doi: 10.17660/ ActaHortic.2013.986.5

Smith, E., M. Velásquez, L. Zuluaga, and J. Valerin. 2010. Efecto de la densidad de población sobre el crecimiento y producción de plantas en primera generación de banano dátil (Musa AA). Agron. Costarr. 34(1), 77-83. Doi: 10.15517/rac.v34i1.6701 
Solarte, M., L. Pérez, and L. Melgarejo. 2010. Ecofisiología vegetal. pp. 137-166. In: Melgarejo, L. (ed.). Experimentos en fisiología vegetal. Universidad Nacional de Colombia, Bogota.

Surendar, K., D. Devi, P. Jeyakumar, K. Velayudham, and I. Ravi. 2015. Changes in proline and polyphenol oxidase enzyme activity in some banana cultivars and hybrids under water stress. Genom. Appl. Biol. 6(4), 1-6. Doi: 10.5376/gab.2015.06.0004

Thippesha, D., V. Srinivas, B. Sriharsha, G. Janardhan, and B. Mahanthesh. 2008. Effect of planting systems, spacing and nutrition on dry matter production on distribution in banana cv. Robusta. Asian J. Hortic. 3(2), 297-300.

Toro, A., R. Ortega, M. Vázquez, and L. Ibáñez. 2016. Requerimientos de riego y predicción del rendimiento en el cultivo de banano mediante un modelo de simulación en el Urabá antioqueño, Colombia. Rev. Tecnol. Cienc. Agua 7(6), 105-122.

Torres, J. 2016. Absorción, distribución y acumulación de nitrógeno en banano variedad Williams en dos ciclos de producción en zona húmeda tropical. $\mathrm{PhD}$ thesis. Universidad Nacional de Colombia, Bogota.

Turner, D., J. Fortescue, and D. Tomas. 2007. Environmental physiology of the bananas (Musa spp). Braz. J. Plant Physiol. 19(4), 463-484. Doi: 10.1590/ S1677-04202007000400013

Turner, D., J. Fortescue, and D. Thomas. 2009. Bananas: Environment and crop physiology. pp. 1-30. In: DaMatta, F. (ed). Ecophysiology of tropical tree crops. Nova Science Publishers, New York, NY.

Urban, J., M. Ingwers, M. McGuire, and R. Teskey. 2017. Stomatal conductance increases with rising temperature. Plant Signal. Behav. 12(8), e1356534. Doi: 10.1080/15592324.2017.1356534

Vargas, A. and J. Sandoval. 2005. Evaluación agronómica, de producción y de calidad de Yangambi (AAA) y Dátil (AA). InfoMusa 14(1), 6-10.

Vargas-Calvo, A., P. Chinchilla-Acuña, and H. Valle-Ruiz. 2015. La emisión foliar en plátano y su relación con la diferenciación floral. Agron. Mesoam. 26(1), 119-128. Doi: 10.15517/am.v26i1.16935 